\title{
Odontochilus putaoensis (Orchidaceae), a new record and key to the genus for China
}

\author{
Sun M. ${ }^{1}$, Jin Y. ${ }^{1}$, Huang J. ${ }^{1}$, Kumar P. ${ }^{2} \&$ H.Z. Tian ${ }^{1 *}$ \\ ${ }^{1}$ School of Life Sciences, East China Normal University, Shanghai - 200 241, PR China \\ ${ }^{2}$ Kadoorie Farm and Botanic Garden, Lam Kam Road, Lam Tsuen, Tai Po, New Territories, Hong Kong SAR, PR China \\ *E-mail: thz0102@126.com
}

\begin{abstract}
Odontochilus putaoensis X.H.Jin, L.A.Ye \& A.T.Mu, a jewel orchid hitherto known only from Myanmar and Laos, is recorded from China for the first time. A detailed morphological description and a colour figure are provided, together with information on habitat, distribution and tentative conservation status. An updated identification key to the genus Odontochilus in China is also provided.
\end{abstract}

Keywords: Flora, Jewel orchid, Key, Taxonomy.

\section{Introduction}

Odontochilus Blume (Orchidaceae, subtribe Goodyerinae, tribe Cranichideae) includes autotrophic or rarely holomycotrophic, terrestrial or lithophytic herbs with a creeping rhizome that is cylindric and fleshy. Species of Odontochilus usually have bifid epichiles and mesochiles decorated with filaments or teeth and subglobose hypochiles containing a pair of fleshy calli. In addition, their columns usually have two wings and the stigmatic lobes separate to confluent, located below rostellum (Chen et al., 2009).

Odontochilus includes 70 species distributed from North India and Himalaya to Japan, Southeast Asia, and the southwestern Pacific. In China, the genus is represented by 20 species and one subspecies (seven species and one subspecies endemic), of which nine species have been found in Yunnan Province (Chen et al., 2009; Pedersen, 2011; Lin et al.,

Received: 07.05.2021; Revised \& Accepted: 29.08.2021

Published Online: 16.10.2021
2016; Shaw, 2016; Tang et al., 2016; Yukawa, 2016; Zhou et al., 2016; Chen et al., 2019; Govaerts et al., 2021).

Based on floral morphology, the genus is found to be closely related to Chamaegastrodia Makino \& F.Maek. and Anoectochilus Blume. Being found polyphyletic in recent molecular studies, the genus has been expanded to include Evrardianthe Rauschert, Kuhlhasseltia J.J.Sm., Myrmechis Blume, Pristiglottis Cretz. \& J.J.Sm. and Vexillabium F.Maek. (Shaw, 2016; Yukawa, 2016; Chen et al., 2019). However, a universal consensus is yet to be made in this regard with Bhattarcharjee and Chowdhery (2018) who treated Myrmechis as a distinct genus. Even the generic assignments of various species in this genus are still unsettled. Among these, Odontochilus poilanei (Gagnep.) Ormerod and O. guangdongensis S.C.Chen, S.W.Gale \& P.J.Cribb are worth noticing in this regard. Unlike most species of Odontochilus, they are holomycotrophic. In the molecular phylogeny of Liu (2015), they were clustered together with other species of Chamaegastrodia, which implies that more research is needed. Taxonomic issues pertaining members of genus Chamaegastrodia and Anoectochilus are outside the scope of the current article, hence, we follow Govaerts et al. (2021).

During our fieldwork in Malipo County, Yunnan Province, in November 2019, a small population of Odontochilus caught our attention. It was different from all known members of the genus Odontochilus in China. It was subsequently identified as $O$. putaoensis X.H.Jin, L.A.Ye \& A.T.Mu, a species 
previously recorded only from Myanmar (Aung et al., 2018) and Laos (Lanorsavanh et al., 2019). The population discovered in Malipo represents a new distributional record of O. putaoensis for China.

\section{Materials and Methods}

Voucher specimens of O. putaoensis were collected from Malipo, Yunnan, and deposited in the herbarium of East China Normal University (HSNU). Measurements for O. putaoensis from China were based on one dried specimen, field photographs, and three flowers stored in 50\% ethanol. Measurements for O. putaoensis from Myanmar and Laos were based on literature (Aung et al., 2018; Lanorsavanh et al., 2019).

\section{Taxonomic Treatment}

Odontochilus putaoensis X.H.Jin, L.A.Ye \& A.T.Mu, PhytoKeys 103: 20. 2018. Type: MYANMAR, Kachin state, Putao township, Hponkanrazi Wildlife Sanctuary, X.H. Jin et al. PTET 959 (PE, n.v.).

Fig. 1

Vernacular name: 葡萄齿唇兰 (pu tao chi chun lan in Mandarin).

Terrestrial herbs, autotrophic, 18-60 cm long. Rhizomes creeping, cylindric, fleshy. Roots fibrous, arising from rhizome nodes. Stems ascending, terete, pubescent, 2-7-leaved, internodes 1.5-3.5 $\mathrm{cm}$ long. Leaves alternate, laminae ovate-lanceolate or ovate-elliptic, $2.5-9.7 \times 2.5-4.2 \mathrm{~cm}$, base cuneate, margins entire, apex acute, glabrous, dark green; petiole like base plus tubular sheath 1-4 cm long. Inflorescence erect, terminal, racemose, 12-16flowered; peduncles c. $4 \mathrm{~cm}$ long, pubescent, reddish-brown, with several sterile bracts; rachis $c$. $7.5 \mathrm{~cm}$ long, pubescent. Pedicelled ovary cylindric, twisted, sparsely pubescent. Floral bracts ovate lanceolate, $c .0 .8-1.2 \times 0.4 \mathrm{~cm}$, shorter or nearly as long as pedicelled ovary, apex long acuminate, membranous, abaxially pubescent, reddish brown. Flowers resupinate. Sepals separate. Dorsal sepal forming a hood with petals, ovate to orbicular, 6$7.5 \times 3-4 \mathrm{~mm}$, apex acute, abaxially pubescent, dark greenish brown to reddish brown. Lateral sepals elliptic, oblique, 8-9 × 4-5 $\mathrm{mm}$, apex acute, abaxially pubescent, dark greenish brown to reddish brown. Petals obliquely ovate-falcate, 5-7.5 × 3-4 $\mathrm{mm}$, apex acute, membranous, glabrous, white or white tinted with reddish brown. Labellum Tshaped, curled up, 10-12 mm long, light yellow or white; hypochile sub globose, bi-saccate, 1.2-2 mm in diam., with central septum and a pair of lamellar calli which apically emarginate; mesochile 4-5 mm long, with pair of pectinate flanges, each flange with two or three narrow filaments, one broad tooth, narrow filaments 1.5-4 mm long, broad blade-like or triangular tooth, 1-3 mm long; epichile bi-lobed, lobes erect, diverging at obtuse angle to each other, elliptic, concave, 5-5.5 × 2-3 mm, margins entire, apex obtuse. Column stout, c. $1 \mathrm{~mm}$ long, ventrally with pair of lamellate appendages; appendages nearly axe-shaped, $c .1 \times 1 \mathrm{~mm}$; rostellum bifid, $c .3$ $\mathrm{mm}$ long, apex twisted; anther acuminate in front, c. $4 \mathrm{~mm}$ long, apex twisted; pollinia two, clavate or obovate-clavate, c. $4 \mathrm{~mm}$ long; stigma lobes confluent.

Flowering \& fruiting: Flowering from October to December. The plants found in Myanmar flowered in October (Aung et al., 2018), and the population recorded from Laos flowered in December (Lanorsavanh et al., 2019). In China, we observed the flowers at the beginning of November, but they were fading, thus we assume that the population we found also started to flower in October. Fruit not seen.

Habitat: Plants were found growing in damp places in evergreen broad leaved forests, in association with other Orchidaceae such as Anoectochilus roxburghii (Wall.) Lindl. and Zeuxine nervosa (Wall. ex Lindl.) Benth. ex Trimen, at an elevation of about $1100 \mathrm{~m}$.

Distribution: China, Laosand Myanmar.

Specimen examined: CHINA, Yunnan, Malipo, $c$. 1130 m, 03.11.2019, H.Z. Tian \& M. Sun 20191103039 (HSNU00079857). 

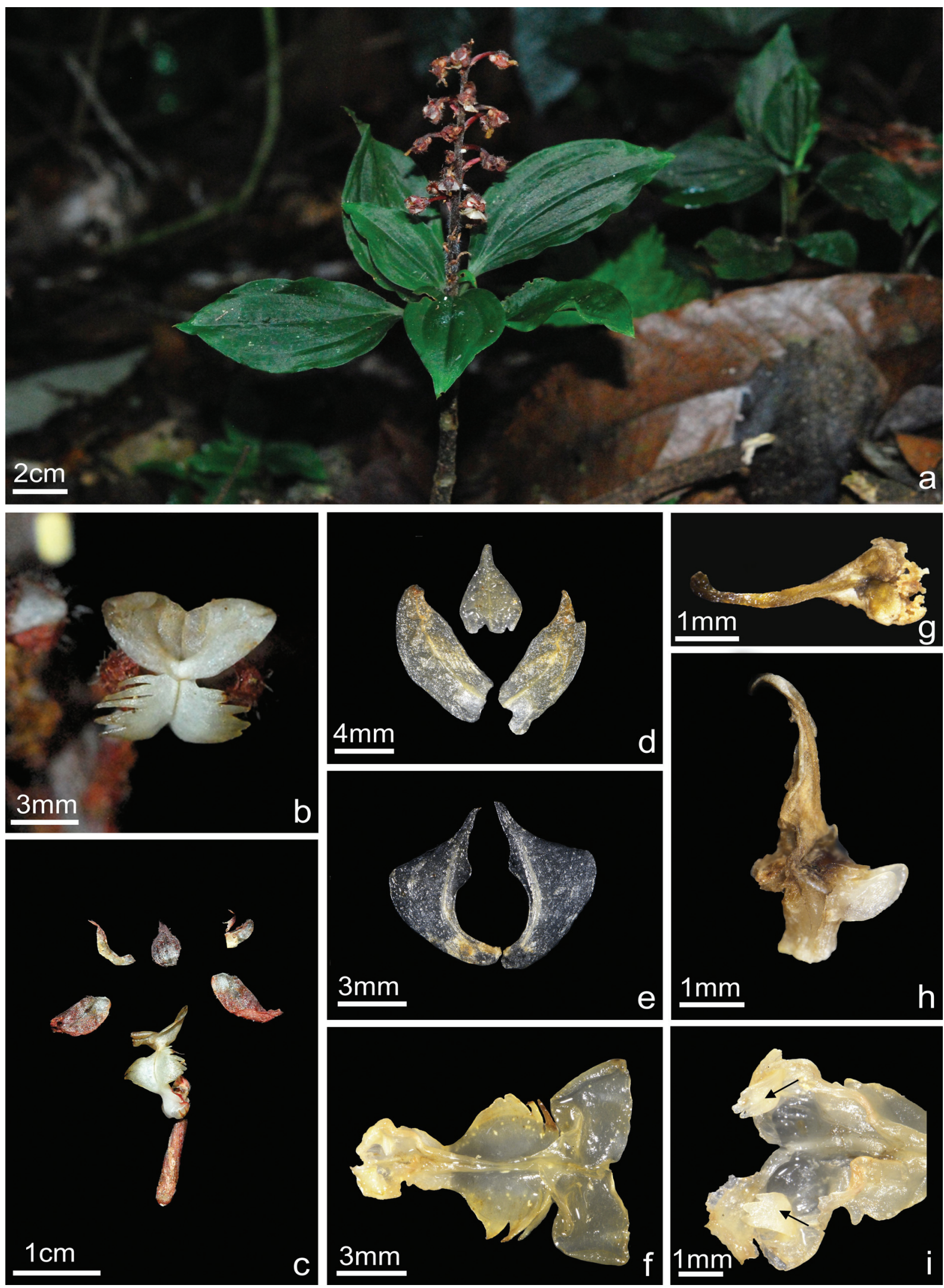

Fig. 1. Odontochilus putaoensis X.H.Jin, L.A.Ye \& A.T.Mu: a. Habit; b. Flower (front view); c. Dissected flower (front view); d. Sepals (dorsal view); e. Petals (front view); f. Lip (front view); g. Pollinia; h. Column (lateral view); i. Hypochile (arrows point to the calli); Some flowers (d-i) have been soaked in 50\% ethanol and are more yellow than in fresh specimens (from H.Z. Tian \& M. Sun 20191103039; photos by H.Z. Tian \& M. Sun). 
Conservation status: Including the site in Malipo County, China, three populations of this species have been discovered so far. The first population being in the Hponkanrazi Wildlife Sanctuary in Putao township, Myanmar, which was reported to contain c. 200 mature individuals (Aung et al., 2018). The second population was found in Laos in Phou Chom Voy Provincial Protected Area with 15 mature individuals (Lanorsavanh et al., 2019). The population found in Malipo County, China, comprised around 20 mature individuals and is located outside the protected area and in close vicinity of a village. Hence, the known overall population size comprised of around 235 mature individuals. However, owing to such a disjunct distribution range, the species is likely to occur in similar habitats in intervening regions. To ascertain this, extensive fieldwork is needed. Due to these limitations, the species is assessed as Data Deficient [DD] following the IUCN guidelines (IUCN, 2019).

Notes: The individuals from China and Laos both have milky white lips (Lanorsavanh et al., 2019), whereas the ones from Myanmar have light yellow lips. The plants we observed and the ones reported from Laos were found at the end of the flowering period, whereas the ones in Myanmar were in full bloom, hence this variation may be a result of the maturity state of the flowers. Most species of Odontochilus have white lips with pale green or yellow pectinate flanges, some others have yellow lips, such as O. lanceolatus (Lindl.) Blume and $O$. clarkei Hook.f.. Therefore, it is unclear whether the variable lip colours of O. putaoensis may be attributable to intraspecific genetic variation, different microhabitat conditions and/or different stages of maturity of the flowers. More studies are required here.

\section{Key to the species of Odontochilus in China}

1. Plants holomycotrophic, leafless .................. 2

1. Plants autotrophic, leafy ................................ 4
2. Flowers resupinate; lip white

O. saprophyticus

2. Flowers not resupinate; lip orange or light yellow 3

3. Dorsal sepal c. $7 \times 4 \mathrm{~mm}$; lip orange-yellow, with a pair of elongate introrse lobules at the epichile lobes O. poilanei

3. Dorsal sepal c. $4 \times 2 \mathrm{~mm}$; lip light yellow, without a pair of elongate introrse lobules at the epichile lobes O. guangdongensis

4. Flowers non-resupinate O. napoensis

4. Flowers resupinate 5

5. Sepals connate in their basal part; column without lamellate appendages 6

5. Sepals separate; column with a pair of lamellate appendages

6. Sepals shallowly connate at the base

O. yakushimensis

6. Sepals connate for about half of their length O. nakaianus

7. Leaves usually less than $1.5 \mathrm{~cm}$ in length; anther apex not twisted 8

7. Leaves usually more than $1.5 \mathrm{~cm}$ in length; anther apex twisted 12

8. Epichile entire, occasionally slightly emarginate; calli subquadrate

8. Epichile obviously bifid; calli transversely elliptic or sub-oblong 10

9. Petals ovate; lip c. $5 \mathrm{~mm}$ long, epichile obcordate or obovate, 1-1.5 mm wide

O. chinensis

9. Petals ovate-oblong; lip c. $7 \mathrm{~mm}$ long, epichile transversely oblong to obtriangular, 3-3.5 mm wide

O. japonicus

10. Sepals $8-9$ mm long; petals oblique; lip 10-12 $\mathrm{mm}$ long; calli suboblong, bidentate O. drymoglossifolius

10. Sepals 5-7 mm long; petals not oblique; lip 7$8 \mathrm{~mm}$ long; calli transversely elliptic, apex obtuse, truncate or slightly concave 11 
11. Petals broadly ovate, urceolate, c. $3.5 \mathrm{~mm}$ wide; mesochile entire O. urceolatus

11. Petals oblanceolate-oblong, c. $2 \mathrm{~mm}$ wide; mesochile serrulate O. pumila

12. Leaves less than $2 \mathrm{~cm}$ long 13

12. Leaves more than $2 \mathrm{~cm}$ long 14

13. Lip without reddish purple spots, mesochile with short irregular teeth O. crispus

13. Lip with reddish purple spots, mesochile with fimbriate filaments O. nanlingensis

14. Lip curved upwards O. putaoensis

14. Lip stretched forward 15

15. Lip yellow ..... 16

15. Lip white or light yellow 18

16. Ovary pubescent; sepals and petals with a deep purplish red stripe on each side of mid-vein; lip yellow tinted with purplish red .... O. clarkei

16. Ovary glabrous or pubescent in its distal part; sepals yellowish green; petals whitish green; lip yellow

17. Without two flesh appendages on either side of the column; rostellum bifid O. lanceolatus

17. With two flesh appendages on either side of the column; rostellum twisted .... O. bisaccatus

18. Sepals and petals with conspicuous dark-green or brownish-green patches. O. tashiroi

18. Sepals and petals without patches or with weaker dark-green patches. 19

19. Sepals and petals without patches; mesochile margin with slender filaments O. elwesii

19. Sepals and petals with weak dark-green patches; mesochile margin with short and wide irregular teeth

20. Ovary apex straight; lateral sepals spreading O. tortus

20. Ovary apex downcurved; lateral sepals not spreading
21. Sepals and petals with dark green tessellation; mesochile have short irregular teeth O. brevistylis

21. Sepals and petals without dark green tessellation; mesochile have long fringes ....... O. brevistylis subsp. candidus

\section{Acknowledgements}

We are thankful to the Yunnan Provincial Department of Forestry for their assistance during our field survey, and are also grateful to Biodiversity Survey, Observation and Assessment Program of Ministry of Ecology and Environment (MEE) of China for financial support.

\section{Literature Cited}

AUNG Y.L., MU A.T. \& X.H. JIN 2018. Odontochilus putaoensis (Cranichideae, Orchidaceae), a new species from Myanmar. PhytoKeys 103: 19-26. https://doi.org/ 10.3897/phytokeys.103.25913

BHATTACHARJEE A. \& H.J. CHOWDHERY 2018. Fascicles of Flora of India, Fascicle 28: Orchidaceae: Orchidoideae: Cranichideae: Subtribe Goodyerinae. Botanical Survey of India, Kolkata.

CHEN S.P., TIAN H.Z., GUAN Q.X., ZHAI J.W., ZHANG G.Q., CHEN L.J., LIU Z.J., LAN S.R. \& M.H. LI 2019. Molecular systematics of Goodyerinae (Cranichideae, Orchidoideae, Orchidaceae) based on multiple nuclear and plastid regions. Molecular Phylogenetics and Evolution 139: 106542. https://doi.org/ 10.1016/j.ympev.2019.106542

CHEN X.Q., GALE S.W., CRIBB P.J. \& P. ORMEROD 2009. Odontochilus. In: WU Z.Y., RAVEN P.H. \& D.Y. HONG (eds.), Flora of China. Volume 25. Science Press, Beijing and Missouri Botanical Garden Press, St. Louis. pp. $80-84$.

GOVAERTS R., BERNET P., KRATOCHVIL K., GERLACH G., CARR G., ALRICH P., PRIDGEON A.M., PFAHL J., CAMPACCI M.A., BAPTISTA HOLLAND D., TIGGES H., SHAW J., CRIBB P., GEORGE A., KREUZ K. \& J. WOOD 2021. World Checklist of Orchidaceae. Facilitated by the Royal Botanic Gardens, Kew. Available at: http://wcsp.science.kew. org/ (Accessed on16.09.2021).

IUCN. 2019. Guidelines for using the IUCN Red List Categories and Criteria. Version 14. Prepared by the 
Standards and Petitions Committee. Available at: http:/ /www.iucnredlist.org/documents/RedListGuidelines. pdf (Accessed on 15.03.2021)

LANORSAVANH S., SOUVANNAKHOUMMANE K., KUMAR P., GALE S.W., LAMXAY V., BOUNPHANMY S. \& K. CHANTHAVONGSA 2019. Two new distribution records of Odontochilus Blume (Orchidaceae) from Laos. Thai Journal of Botany 11: 85-93.

LIN T.P., LIU H.Y., HSIEH C.F. \& K.H. WANG 2016. Complete list of the native orchids of Taiwan and their type information. Taiwania 61: 78-126. https://doi.org/ 10.6165/TAI.2016.61.78

LIU Q.X. 2015. Phylogenetic systematic study on Anoectochilus s. l. (Orchidaceae) in China. M.Sc Dissertation, (unpublished), East China Normal University, Shanghai.

PEDERSEN H.Æ. 2011. Odontochilus. In: SANTISUK T. \& K. LARSEN (eds.), Flora of Thailand. Volume 12 (1). The Forest Herbarium, Department of National Parks,
Wildlife and Plant Conservation, Bangkok. pp. 184196.

SHAW J.M.H. 2016. Quarterly supplement to the international register and checklist of Orchid hybrids (Sander's list): January-March 2016 registrations. Orchid Review 124: 22-40.

TANG H., FENG H.Z. \& Y.F. HUANG Y.F. 2016. Odontochilus napoensis sp. nov. (Orchidoideae: Orchidaceae) from southwestern Guangxi, China. Nordic Journal of Botany 34: 405 408. https://doi.org/ 10.1111/njb.00944

YUKAWA T. 2016. Taxonomic notes on the Orchidaceae of Japan and adjacent regions. Bulletin of the National Museum of Nature and Science Series B (Botany) 42: 103-111.

ZHOU X.X., CHENG Z.Q., LIU Q.X., ZHANG J.L., HU A.Q., HUANG M. Z., HU C. \& H.Z. TIAN 2016. An updated checklist of Orchidaceae for China, with two new national records. Phytotaxa 276: 1-148. https:// doi.org/10.11646/phytotaxa.276.1.1 